\title{
Palliative care in home care for cancer patients in Brazil
}

\author{
Cuidados paliativos na atenção domiciliar para pacientes oncológicos \\ no Brasil
}

Adriana Tavares de Moraes Atty', Jeane Glaucia Tomazelli2

\begin{abstract}
The organization of health services must consider the integral care of the individual with cancer, ensuring, when necessary, palliative care. The objective of this study was to describe the profile of oncology users in palliative care in home care. A descriptive study was carried about the cancer cases registered in home care during the period 2013-2015 in the Country. Only the states of Roraima, Sergipe and Espírito Santo did not register cases. Among the ten most recurrent types of neoplasias were the most incidental, among men, of prostate, and among women, of breast. However, in stratification by age group, differences between the most prevalent types of tumors were observed. In men $<40$ years, encephalon was the most recurrent type, and among the $>60$ years, it was prostate. In women, with the exception of $<40$ years, breast cancer was the most recurrent. The description of the profile of users with malignant neoplasias assisted in the home care allows a better understanding of the flow of these users in the network, allowing the monitoring of the care line.
\end{abstract}

KEYWORDS Palliative care. Home care services. Health information systems. Neoplasias.

RESUMO A organização de serviços de saúde deve considerar o cuidado integral do indivíduo com câncer, garantindo, quando necessário, os cuidados paliativos. O objetivo do trabalho foi descrever o perfil dos usuários oncológicos em cuidados paliativos na atenção domiciliar. Realizouse estudo descritivo dos casos de câncer registrados na atenção domiciliar no período 2013-2015 no País. Somente os estados de Roraima, Sergipe e Espírito Santo não registraram casos. Entre os dez tipos de neoplasias mais recorrentes estavam as mais incidentes, entre homens, de próstata, e entre mulheres, de mama. Mas, na estratificação por faixa etária, observaram-se diferenças entre os tipos mais prevalentes de tumores. Em homens $<40$ anos, encéfalo foi o tipo mais recorrente, e entre os $>60$ anos, foi próstata. Nas mulheres, com exceção das $<40$ anos, o câncer de mama foi o mais recorrente. A descrição do perfil dos usuários com neoplasias malignas assistidos na atenção domiciliar permite conhecer melhor o fluxo desses usuários na rede, possibilitando o

1 Instituto Nacional de Câncer José Alencar Gomes da Silva (Inca) Rio de Janeiro (RJ), Brasil. aatty@inca.gov.br

$\mathbf{2}$ Instituto Nacional de Câncer José Alencar Gomes da Silva (Inca) Rio de Janeiro (RJ), Brasil. jtomazelli@inca.gov.br
PALAVRAS-CHAVE Cuidados paliativos. Serviços de assistência domiciliar. Sistema de informação em saúde. Neoplasias. 


\section{Introduction}

According to the World Health Organization $(\mathrm{WHO})^{\mathbf{1}}$, palliative care is a type of approach aimed at improving the quality of life of patients and their families at the risk of death associated with a disease.

To ensure quality of life, well-being, comfort and human dignity, palliative care should be person-centered, valuing the needs of the patient so that the patient receives adequate and culturally appropriate information about his/her health status and his or her role in the outlets decisions on the treatment received ${ }^{2}$.

It is important that palliative care be part of the care line, which should be included in all levels of care, especially basic care ${ }^{2}$. The network should be integrated and articulated to ensure the patient, under such care, the hospitalization in a palliative care unit, the diagnostic investigation exams and their monitoring, providing safety to the patient and his relatives and sharing the decisions for the end of the life ${ }^{3}$. Inadequate integration of health care in the health care network contributes to the lack of equitable access to health care ${ }^{2}$, compromising the integrality of care.

A public health policy that considers financing mechanisms, the training of health professionals in this area and the guarantee of medicines is fundamental for the development of palliative care ${ }^{4}$. In Brazil, in 2012, only three medical schools were obliged to include palliative care in their educational program. The availability of drugs for pain control (opioids) still faces difficulties due to the control exercised over this type of medication, which, together with the incipient formation of professionals and disinformation, constitutes an obstacle to the treatment of pain ${ }^{5}$. As Silva and Hortale ${ }^{6}$ point out, the structure of oncological palliative care in Brazil is still incipient, and it is necessary to implement initiatives centered on caring for solidarity, understanding death as a natural and irremediable process.
However, the fragility in offering palliative care is not an inherent problem in Brazil. It is observed that, although the highest rate of adults in palliative care per 100 thousand/inhabitants are in highincome countries, the majority of those in need of palliative care (78\%) live in lowand middle-income countries ${ }^{4}$.

And, with population aging, chronic noncommunicable diseases represent a major challenge to the provision of palliative care. In 2011, about 29 million people worldwide died in need of such care, of which $38.5 \%$ died of cardiovascular disease and $34 \%$ of cancer ${ }^{4}$.

The $\mathrm{WHO}^{1,7}$ estimates that only $14 \%$ of people in need of palliative care receive them and that, at least, $80 \%$ of patients with terminal cancer need palliative care, which is especially important in places where a large proportion of patients are diagnosed with cancer in advanced stages and with little chance of cure.

Thus, the epidemiological importance of cancer and its magnitude as a public health problem require policies that aim to contribute to improving the quality of life of users with cancer, through promotion, prevention, early detection, timely treatment and, specially, palliative care.

The Ministry of Health of Brazil (MH), with the intention of implementing policies in the areas of palliative care and assistance for patients with pain, instituted, within the scope of the Unified Health System (SUS), in 2002, the National Program of Assistance to Pain and Palliative Care through Ordinance $\mathrm{MH} / \mathrm{GM} \mathrm{n}^{\circ}$ 198. This was revoked by Administrative Rule $\mathrm{MH} / \mathrm{GM} \mathrm{n}^{\circ}$ $3.150 / 2006^{9}$, which instituted the Technical Chamber in Pain Control and Palliative Care and began to respond to national guidelines on control pain and palliative care, the structuring of care networks in this field and the training and qualification of professionals to work in pain control and palliative care, among other subjects. According to Ugarte ${ }^{3}$, the 2002 Ordinance did not induce the 
provision of palliative care, as expected, in public network services.

According to Rodrigues ${ }^{\mathbf{1 0}}$, palliative care can be provided through three care models: hospital, home and outpatient. Each of them has its advantages and disadvantages, however, home care differs in that it allows the user to be accommodated in his/her own home, close to the family and without the obligation to conform to the hospital routine.

Home care is defined in Ordinance $n^{\circ}$ $963 / 2013$ as a

a new modality of health care, substitute or complementary to existing ones, characterized by a set of actions to promote health, prevention and treatment of diseases and rehabilitation provided at home, with a guarantee of continuity of care and integrated into health care networks ${ }^{\mathbf{1 1}}$.

In order to organize home care in the Country, this Ordinance describes the types of home care teams: Multi-professional Home Care Teams (Emad) (type 1 and type 2) and Multiprofessional Support Teams (Emap); and their type of modalities of organization: home care type $1(\mathrm{AD} 1)$, type 2 (AD2) and type 3 (AD3).

Each modality of home care has its specific characteristics according to the profile of the user and, consequently, with the team responsible for the care delivery. Therefore, the AD1 is intended for users who demand less complex care, and are, thus, in charge of basic care teams. The AD2 and AD3 modalities are intended for users who, due to their physical condition, require more frequent care and continuous monitoring. Both should be provided by Emap or Emad, and what distinguishes them is the period of residence of the user in home care. In $\mathrm{AD} 2$, the permanence can be continuous and, if the health situation of the user becomes more stable, it can be referred to AD1. The AD3 modality is characterized by the continuous permanence of the user, given his health condition. It should be emphasized, therefore, that palliative care falls within the $\mathrm{AD} 2$ and $\mathrm{AD} 3^{12}$ care modalities.

Still in 2013, the current National Cancer Prevention and Control Policy (PNPCC) ${ }^{\mathbf{1 3}}$ reaffirms that palliative care is part of the integral care of cancer patients and ensures that every oncology hospital has an obligation to guarantee such care, which can within the hospital structure itself or can be referenced to the health care network. And it includes home care as an important point of attention in the provision of palliative care, provided that formalized the reference between the qualified hospitals and the teams.

Based on the competency of April 2012, the care modality of Home Care (HC) was included in the Procedures Tables, Medications and OPM (Orthoses, Prostheses and Special Materials) of the SUS ${ }^{\mathbf{1 4}}$, allowing to monitor the actions performed by this type of care, given the structuring of the database in the Ambulatory Information System (SIA/SUS) (SAD - Home Care Service), which began to consolidate the production performed by this type of care, as of November 2012.

Therefore, the present study aims to describe the profile of cancer patients in palliative care in home care.

\section{Methods}

This is a descriptive study, with secondary data from the SIA/SUS available on the website of the Department of Information Technology of SUS (Datasus) (www.datasus. gov.br), for Brazil, in the period from 2013 to 2015 . The study was defined considering that the information would already be consolidated in 2013 and for the last year available at the time of the study, 2015.

The records of the modality of home care were evaluated and only considered for the production performed by Emap and Emad (type 1 or type 2). Such a restriction is justified by the fact that these teams, by 
definition, are able to provide care in modalities $\mathrm{AD} 2$ and $\mathrm{AD} 3$, in which palliative care would be included.

The variables considered to describe the profile of the users were:

- Main diagnosis: malignant neoplasias, according to International Classification of Diseases - ICD-10 (ICD C00-C97);

- Sex;

- Age: categorized in the age groups: under 40 years, 40 to 59 years, 60 to 79 years; 80 years or more;

- Origin of the referral (point of the network responsible for the referral of the user to palliative care);

- Unit of the Federation (UF) of residence of the patient;

- Region of residence of the patient;

Data were analyzed using the Tabwin and Excel 2010 programs.

The informations recorded in the information system were evaluated and described comparatively between the regions of the Country, between the neoplasias and between the age groups. The study is exempt from being submitted to the ethics committee for using unrestricted access secondary data.

\section{Results}

It is stressed in this study the amount of oncology patients reported in palliative care in the home care in the period considered, ranging from 3.748 , in 2013 , to 8.651 , in 2015 , equivalent to a $131 \%$ increase (table 1 ).

Among the states of Brazil, only Roraima, Sergipe and Espírito Santo did not register cases of patients in palliative care for cancer throughout the study period. And the state of Amapá and the Federal District registered a reduction of more than $50 \%$ of patients in palliative care from 2013 to 2015 . In all regions of the Country, there was an increase in the rate of palliative care per 100.000 inhabitants, highlighting the North region, with an increase above $300 \%$, while the South region recorded the smallest increase (table 1). 
Table 1. Rate of cancer patients in palliative care in home care per 100.000 inhabitants, per year, Unit of residence of the Federation. Brazil and Regions, 2013-2015

\begin{tabular}{|c|c|c|c|c|c|c|}
\hline \multirow{2}{*}{ Region and UF } & \multicolumn{3}{|c|}{ Total patients } & \multicolumn{3}{|c|}{ Rate per 100.000 inhabitants } \\
\hline & 2013 & 2014 & 2015 & 2013 & 2014 & 2015 \\
\hline NORTH & 55 & 174 & 255 & 0,32 & 1,01 & 1,46 \\
\hline Acre & - & 8 & 23 & 0,00 & 1,01 & 2,86 \\
\hline Amapá & 17 & 2 & 4 & 2,31 & 0,27 & 0,52 \\
\hline Amazonas & 1 & 16 & 41 & 0,03 & 0,41 & 1,04 \\
\hline Pará & 18 & 60 & 108 & 0,23 & 0,74 & 1,32 \\
\hline Rondônia & 12 & 72 & 67 & 0,69 & 4,12 & 3,79 \\
\hline Roraima & - & - & - & 0,00 & 0,00 & 0,00 \\
\hline Tocantins & 7 & 16 & 12 & 0,47 & 1,07 & 0,79 \\
\hline NORTHEAST & 756 & 1664 & 1878 & 1,35 & 2,96 & 3,32 \\
\hline Alagoas & 94 & 191 & 217 & 2,85 & 5,75 & 6,50 \\
\hline Bahia & 228 & 635 & 554 & 1,52 & 4,20 & 3,64 \\
\hline Ceará & 83 & 191 & 337 & 0,95 & 2,16 & 3,78 \\
\hline Paraíba & 30 & 93 & 82 & 0,77 & 2,36 & 2,06 \\
\hline Pernambuco & 270 & 476 & 561 & 2,93 & 5,13 & 6,00 \\
\hline Piauí & 1 & 33 & 50 & 0,03 & 1,03 & 1,56 \\
\hline Rio Grande do Norte & - & 8 & 30 & 0,00 & 0,23 & 0,87 \\
\hline Sergipe & - & - & - & 0,00 & 0,00 & 0,00 \\
\hline Maranhão & 50 & 37 & 47 & 0,74 & 0,54 & 0,68 \\
\hline CENTRAL-WEST & 240 & 458 & 656 & 1,60 & 3,01 & 4,25 \\
\hline Distrito Federal & 192 & 212 & 57 & 6,88 & 7,43 & 1,96 \\
\hline Goiás & 37 & 150 & 187 & 0,58 & 2,30 & 2,83 \\
\hline Mato Grosso & - & - & 2 & 0,00 & 0,00 & 0,06 \\
\hline Mato Grosso do Sul & 11 & 96 & 410 & 0,43 & 3,66 & 15,46 \\
\hline SOUTHEAST & 2099 & 3804 & 4787 & 2,49 & 4,47 & 5,58 \\
\hline Minas Gerais & 159 & 433 & 769 & 0,77 & 2,09 & 3,68 \\
\hline Espírito Santo & - & - & - & 0,00 & 0,00 & 0,00 \\
\hline Rio de Janeiro & 300 & 553 & 518 & 1,83 & 3,36 & 3,13 \\
\hline São Paulo & 1640 & 2818 & 3500 & 3,76 & 6,40 & 7,88 \\
\hline SOUTH & 598 & 788 & 1075 & 2,08 & 2,72 & 3,68 \\
\hline Paraná & 225 & 256 & 326 & 2,05 & 2,31 & 2,92 \\
\hline Rio Grande do Sul & 309 & 435 & 578 & 2,77 & 3,88 & 5,14 \\
\hline Santa Catarina & 64 & 97 & 171 & 0,96 & 1,44 & 2,51 \\
\hline BRAZIL & 3748 & 6888 & 8651 & 1,86 & 3,40 & 4,23 \\
\hline
\end{tabular}

Source: Ambulatory Information System (SIA/SUS).

Note: '-' without information. 
During the whole period, there was a predominance of males in palliative care in home care, increasing over the years, accounting for $55 \%$ of cases in 2015 (graph 1).

Graph 1. Proportion of patients with malignant neoplasia in palliative care treated at home care by sex and year, Brazil, 2013-2015

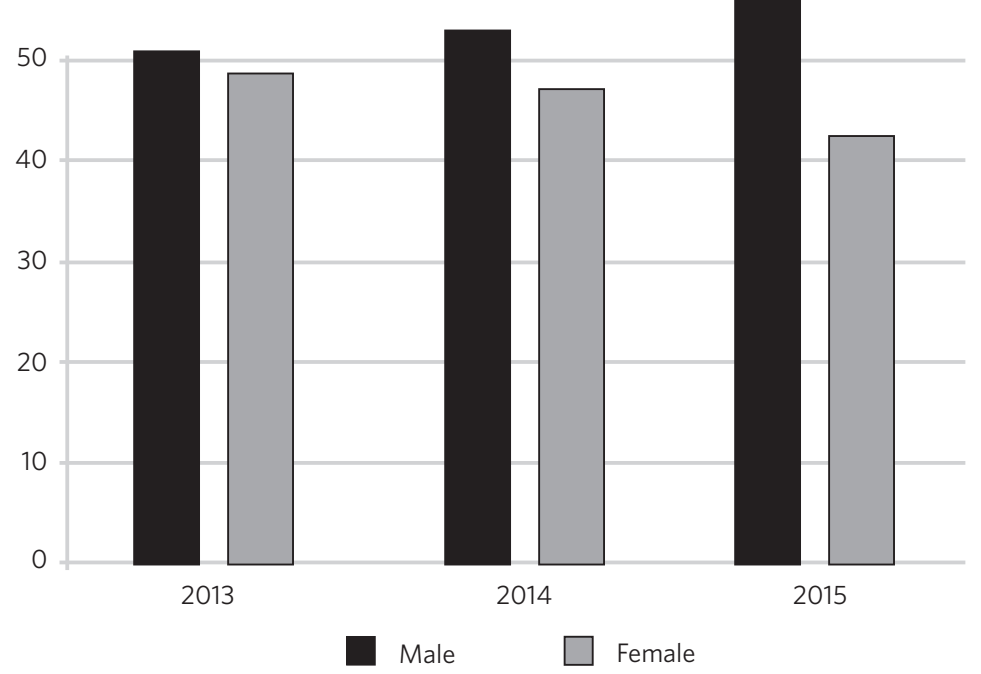

Source: Ambulatory Information System (SIA/SUS).

Of the major neoplasias that required palliative care in home care for men, prostate cancer was the most frequent, followed by lung cancer, in 2013 and 2015, and colon and rectum, in 2014.
For women, the most frequent in three years was malignant neoplasm of breast, followed by that of encephalon, in 2013, and of colon and rectum, in 2014 and 2015 (chart 1).

Chart 1. Most frequent malignant neoplasia of palliative care patients attended at home care by sex and year, Brazil, 20132015

\begin{tabular}{ll}
\hline MEN & \multicolumn{2}{c}{ WOMEN } \\
\hline Prostate & Breast \\
Bronchi and lungs & Encephalon \\
Colon and rectum & Colon and rectum \\
Larynx & Bronchi and lungs \\
Encephalon & Cervix \\
Stomach & Another malignant neoplasia of the skin \\
Esophagus & Stomach \\
\hline
\end{tabular}


Chart 1. (cont.)

\begin{tabular}{|c|c|}
\hline Multiple myeloma and malignant neoplasia of plasma cells & Esophagus \\
\hline Small intestine & Ovary \\
\hline Another malignant neoplasia of the skin & Pancreas \\
\hline \multicolumn{2}{|c|}{2014} \\
\hline MEN & WOMEN \\
\hline Prostate & Breast \\
\hline Colon and rectum & Colon and rectum \\
\hline Larynx & Encephalon \\
\hline Bronchi and lungs & Bronchi and lungs \\
\hline Encephalon & Cervix \\
\hline Esophagus & Stomach \\
\hline Stomach & Liver intra-hepatic bile ducts \\
\hline Oropharynx & Another malignant neoplasia of the skin \\
\hline $\begin{array}{l}\text { Spinal cord, cranial nerves, and other parts of the central } \\
\text { nervous system }\end{array}$ & Larynx \\
\hline Small intestine & Small intestine \\
\hline \multicolumn{2}{|c|}{2015} \\
\hline HOMENS & MULHERES \\
\hline Prostate & Breast \\
\hline Bronchi and lungs & Colon and rectum \\
\hline Colon and rectum & Bronchi and lungs \\
\hline Larynx & Cervix \\
\hline Encephalon & Encephalon \\
\hline Stomach & Stomach \\
\hline Esophagus & Esophagus \\
\hline Multiple myeloma and malignant neoplasia of plasma cells & Liver intra-hepatic bile ducts \\
\hline Small intestine & Ovary \\
\hline Another malignant neoplasia of the skin & Multiple myeloma and malignant neoplasia of plasma cells \\
\hline
\end{tabular}

Source: Ambulatory Information System (SIA/SUS).

In the distribution of the five most frequent neoplasias in men and women in palliative care in home care by age group, it is observed that the most frequent tumor changes according to the age group. In women younger than 40 years, the most recurrent neoplasia was colon and rectum. From the age of 40, it became breast cancer, while cases of cervical cancer remained constant in all four age groups. Among men, the occurrence of prostate cancer increases with aging, becoming the most prevalent from the age of 60 . Among those younger than 40 years, the most frequent neoplasms in palliative care were encephalon, followed by colon and rectum. And in the age group of 40 to 59 years, the most frequent one was larynx (figure 1). 
Figure 1. Most frequent neoplasias by age group in women (a) and in men (b) in palliative care for home care, Brazil, $2013-2015$

\section{A}

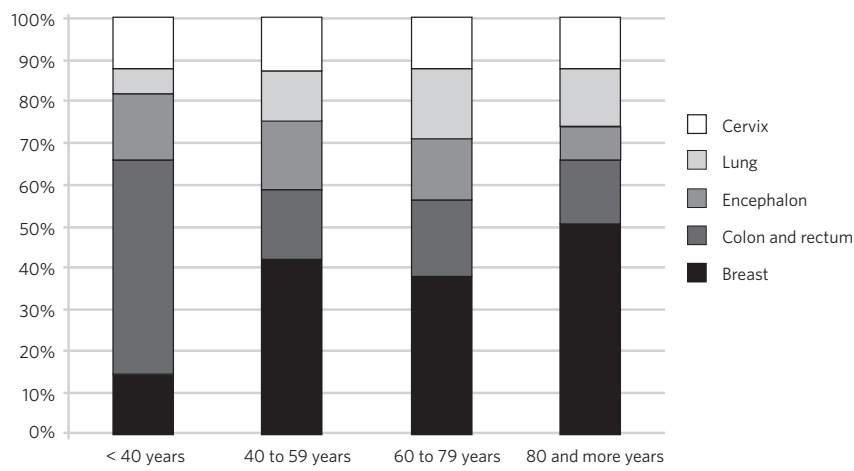

B

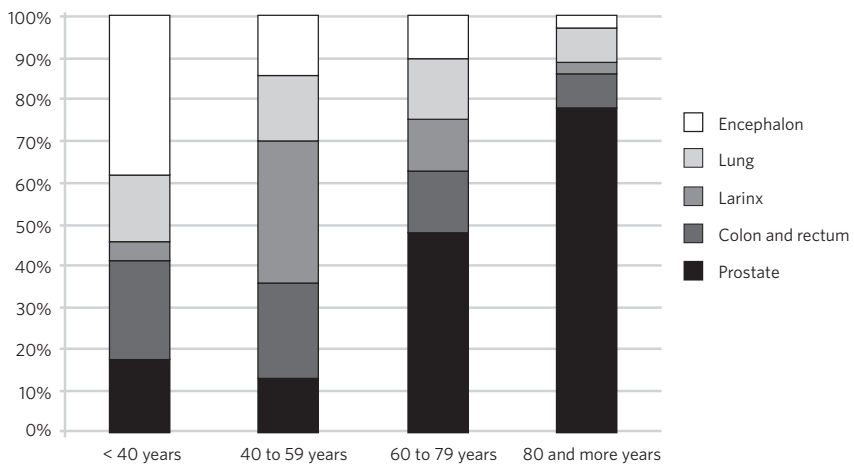

Source: Ambulatory Information System (SIA/SUS).

In the three years analyzed, more than $45 \%$ of referrals in palliative care for home care were performed by primary care. It is observed, as well, a small increase in referrals from hospital admissions and a decrease in referrals made by oncological centers (graph 2).

Graph 2. Point of the network responsible for the referral of patients with malignant neoplasia in palliative care for home care, Brazil, 2013-2015

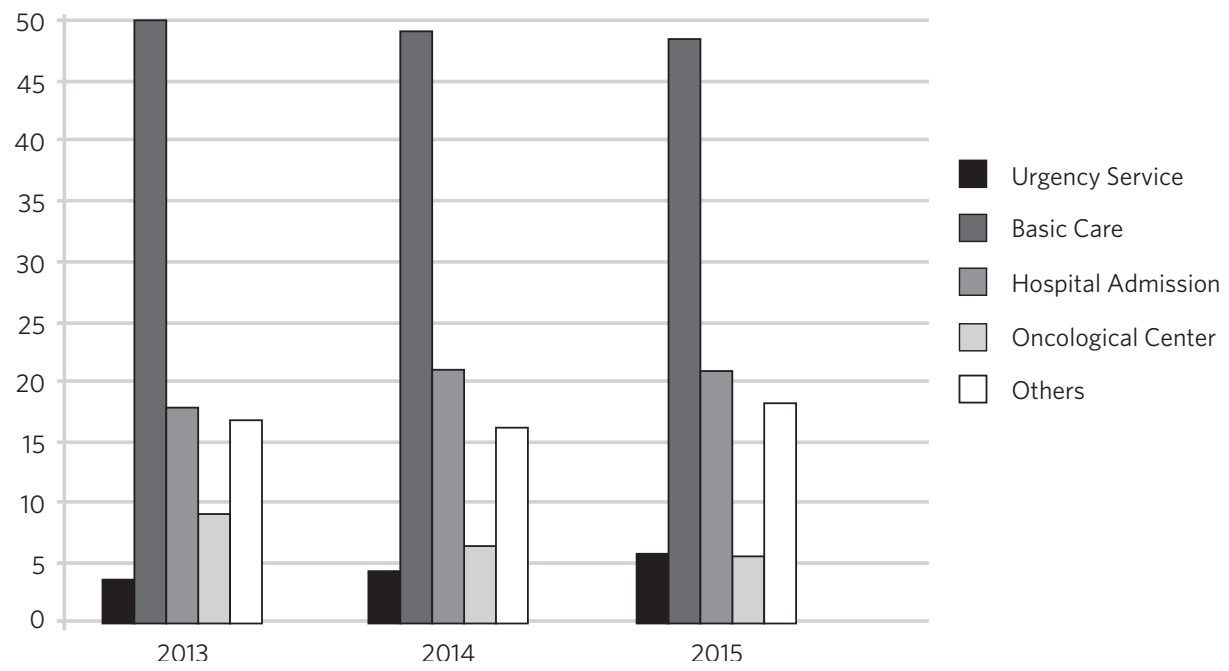

Source: Ambulatory Information System (SIA/SUS). 


\section{Discussion}

The most frequent neoplasias in palliative care patients in home care are the ones that most affect men and women in the Country: prostate and breast cancer, respectively, excluding non-melanoma skin cancer ${ }^{15}$.

Lung, laryngeal and esophageal cancers - which are among the top 10 incidents in men - were also recurrent among palliative care patients in home care. These malignancies have in common tobacco as the main risk factor ${ }^{\mathbf{1 6}, 17}$. Although research ${ }^{\mathbf{1 8}}$ points to a decrease in apparent consumption of tobacco, it remains an important risk factor for non-communicable chronic diseases, especially among individuals with lower education and income ${ }^{\mathbf{1 9}}$.

Among women, the frequency of cases of palliative care for cervical cancer is also in agreement with the incidence of this neoplasm, which is the second most frequent after breast cancer ${ }^{15}$. However, because it is a cancer that can be prevented by the early detection of precursor lesions ${ }^{\mathbf{2 0}}$, through a simple examination and made available in all basic care in the Country, it is worrying that so many cases evolve to the point of requiring palliative care.

Comparing the chart that presented the most recurrent neoplasias per year with the graph that stratified by age, it is perceived that considering the range is an important strategy to achieve the intended objectives with the actions of disease control and early detection and for the scheduling of care, although not all neoplasms related among the five most recurrent by age group are susceptible to early detection actions, such as, for example, the brain and lung'21.

The profile of the network point responsible for the referral of patients with malignant neoplasias in palliative care for home care draws attention to the fact that oncology centers appear with little representativeness compared to basic care. Considering that home care provided by the primary care team presupposes care of less complexity, a possible explanation for this result is the possibility that these teams are taking care in places where the deployment of the AD2 and AD3 teams is still not satisfactory. Therefore, patients referred by the cancer centers for palliative care could be referred to stay in palliative care for basic care. However, this is a hypothesis that needs investigation for better understanding, since the specialized hospital unit should be responsible for the management of this care ${ }^{13}$.

Access to informations on care provided in home care opens a new possibility for analysis of the health care network, which deserves to be explored, given the importance of this care modality. The percentage of cases in advanced stages (stage III and IV) among the five most frequent types of tumors (breast, cervix, colon and rectum, lung and prostate) present in the Hospital Cancer Registries from 2007 to 2011, who may need palliative care in the Country 22 .

The data presented here should not be interpreted as a description of the care reality of each state in Brazil regarding the care provided to cancer patients in home care, since they were extracted from an information system that is still not very mature, because it is recent and because it presents all weaknesses in secondary data. However, it is believed that they may raise the interest of local teams in monitoring the therapeutic itinerary of oncological users to the end of life, as the case may be, as well as ensuring the quality of the information inserted in the information systems, so that these can increasingly subsidize the monitoring of health care networks. 


\section{Conclusions}

This study presents results of interest for monitoring the evolution of different types of cancer and for monitoring the care line, especially for cancers susceptible to early detection.

Even though it presents as a limitation the impossibility of affirming that all oncology patients in home care by Emap and Emad are actually in palliative care, the analysis carried out is an initiative that aims to contribute to the monitoring of the integral care of these patients.

In addition, it highlights the importance of the information systems of the SUS, by making it possible to approximate the epidemiological and care setting, even though this is not the primary purpose of these systems.

It is hoped that, in addition to stimulating the knowledge of the flow of integral cancer patient care, the study contributes to the practice of monitoring and evaluating the health care network regarding palliative care.

\section{Collaborators}

Adriana Tavares de Moraes Atty: participated substantially in the design of the study; acquisition, analysis and interpretation of work data, preparation of the summary and final approval of the version of the abstract to be published. And assumes responsibility for all aspects of the work to ensure that issues related to the accuracy or integrity of any part of the work are duly investigated and resolved. Approved the final version of the manuscript.

Jeane Gláucia Tomazelli: participated substantially in the design of the study; acquisition, analysis and interpretation of work data, preparation of the summary and final approval of the version of the abstract to be published. And assumes responsibility for all aspects of the work to ensure that issues related to the accuracy or integrity of any part of the work are duly investigated and resolved. Approved the final version of the manuscript. 


\section{References}

1. World Health Organization. Cancer control: knowledge into action: WHO guide for effective programmes; module 5. Geneva: World Health Organization; 2007.

2. World Health Organization. Strengthening of palliative care as a component of integrated treatment within the continuum of care [internet]. World Health Organization; 2014 [acesso em 2017 mar 3]. Disponível em: http://apps.who.int/gb/ ebwha/pdf_files/EB134/B134_R7-en.pdf.

3. Ugarte O. Contexto normativo dos cuidados paliativos no SUS [monografia]. [Brasília, DF]: Universidade Federal do Rio Grande do Sul; 2014.

4. Connor SR, Bermedo MCS. Worldwide Palliative Care Alliance, World Health Organization. Global Atlas of Palliative Care at the End of Life. 2014.

5. Pastrana T, Lima L, Wenk R, et al. Atlas de cuidados paliativos na America Latina. Primeira. Houston, USA: AHPC Press; 2012. 37 p.

6. Silva RCF, Hortale VA. Cuidados paliativos oncológicos: elementos para o debate de diretrizes nesta área. Cad Saúde Pública. 2006; 22(10):2055-66.

7. World Health Organization. Noncommunicable diseases and their risk factors - Palliative Care [internet]. [acesso em 2017 mar 3]. Disponível em: http:// www.who.int/ncds/management/palliative-care/ en/.

8. Brasil. Ministério da Saúde. Portaria GM/MS no 19, de 03 de janeiro de 2002. Institui, no âmbito do Sistema Único de Saúde, o Programa Nacional de Assistência à Dor e Cuidados Paliativos. 2002 Jan 3.

9. Brasil. Ministério da Saúde. Portaria GM/MS no 3.150, de 12 de dezembro de 2006. Institui a câmara técnica em controle da dor e cuidados paliativos. Diário Oficial da República Federativa do Brasil. 200612 dez; Seção 1. p. 111.
10. Rodrigues LF. Modalidades de atuação e modelos de assistência em Cuidados Paliativos. In: Manual de Cuidados Paliativos ANCP. Ampliado e atualizado. 2 ed. 2012. 86-93 p.

11. Brasil. Ministério da Saúde. Portaria GM no 963, de 27 de maio de 2013. Redefine a Atenção Domiciliar no âmbito do Sistema Único de Saúde (SUS). 2013 Maio 27 [acesso em 2018 mar 2]. Disponível em: http://bvsms.saude.gov.br/bvs/saudelegis/ gm/2013/prt0963_27_05_2013.html.

12. Brasil. Ministério da Saúde. Secretaria de Atenção à Saúde. Departamento de Atenção Básica. Caderno de atenção domiciliar. Vol. 1. Brasília, DF: Ministério da Saúde; 2012.

13. Brasil. Ministério da Saúde. Portaria GM no 874, de 16 de maio de 2013. Institui a Política Nacional para a Prevenção e Controle do Câncer na Rede de Atenção à Saúde das Pessoas com Doenças Crônicas no âmbito do Sistema Único de Saúde (SUS). Diário Oficial da República Federativa do Brasil. 2013 Maio 29.

14. Brasil. Ministério da Saúde. Portaria SAS no 276, de 30 de março de 2012. Institui o sistema de Registro das Ações Ambulatoriais de Saúde (RAAS). 2012 Mar 30.

15. Brasil. Ministério da Saúde. Instituto Nacional de Câncer José de Alencar Gomes da Silva. Estimativa 2016: incidência de câncer no Brasil. Rio de Janeiro: Instituto Nacional de Câncer José de Alencar Gomes da Silva; 2015. p. 122.

16. Menezes AM, Horta BL, Oliveira ALB, et al. Risco de câncer de pulmão, laringe e esôfago atribuível ao fumo. Rev Saúde Pública. 2002 Abr; 36(2):129-34.

17. Moura MAS, Bergmann A, Aguiar SS, et al. The magnitude of the association between smoking and the risk of developing cancer in Brazil: a multicenter study. BMJ Open. 2014 Fev; 4(2):e003736. 
18. Brasil. Ministério da Saúde. Secretaria-Executiva da CONICQ. Observatório da Política Nacional de Controle do Tabaco [internet]. 2016 [acesso em 2017 mar 2013]. Disponível em: http:// www2.inca.gov.br/wps/wcm/connect/observatorio_controle_tabaco/site/home/dados_numeros/ prevalencia-de-tabagismo.

19. Bazotti A, Finokiet M, Conti IL, et al. Tabagismo e pobreza no Brasil: uma análise do perfil da população tabagista a partir da POF 2008-2009. Ciênc Saúde Coletiva. 2016 Jan; 21(1):45-52.

20. Brasil. Ministério da Saúde. Departamento de Atenção Básica. Rastreamento. Brasília, DF: MS; 2010.
21. World Health Organization. Cancer control: knowledge into action: WHO guide for effective programmes; module 3. Geneva: World Health Organization; 2007.

22. Brasil. Ministério da Saúde. Instituto Nacional de Câncer José de Alencar Gomes da Silva. Informativo Vigilância do Câncer. Perfil da assistência oncológica no Brasil, de 2007 a 2011 [internet]. INCA; 2015 [acesso em 2017 mar 13]. Disponível em: http:// wwwl.inca.gov.br/inca/Arquivos/publicacoes/informativovigilancia2015.pdf.

Received on 01/17/2017

Approved on 11/27/2017

Conflict of interests: non-existent

Financial support: non-existent 